\title{
Effect of Amaranth addition on the nutritional composition and consumer acceptability of extruded provitamin A-biofortified maize snacks
}

\author{
Daniso BESWA ${ }^{1,2}$, Nomusa Rhoda DLAMINI ${ }^{3}$, Muthulisi SIWELA ${ }^{2 *}$, Eric Oscar AMONSOU ${ }^{4}$, Unathi KOLANISI ${ }^{2}$
}

\begin{abstract}
The objective of this study was to determine the effect of adding Amaranth leaf powder on the nutrient content and consumer acceptability of extruded provitamin A-biofortified (PVA) maize snacks. Flours of four varieties of PVA maize were composited with Amaranth leaf powder at 0,1 and $3 \%(\mathrm{w} / \mathrm{w})$ substitution of, respectively, and extruded into snacks. The ash content of the snacks increased from $0.53 \mathrm{~g} / 100 \mathrm{~g}-0.58 \mathrm{~g} / 100 \mathrm{~g}$ to $0.650 \mathrm{~g} / 100 \mathrm{~g}-89 \mathrm{~g} / 100 \mathrm{~g}$ and protein content increased from $9.12 \mathrm{~g} / 100 \mathrm{~g}-10.94 \mathrm{~g} / 100 \mathrm{~g}$ when Amaranth was increased from 0\% to 3\%. Similarly, lysine content increased from $0.10 \mathrm{~g} / 100 \mathrm{~g}$ to $0.17 \mathrm{~g} / 100 \mathrm{~g}$, whilst methionine increased from $0.14 \mathrm{~g} / 100 \mathrm{~g}$ to $0.19 \mathrm{~g} / 100 \mathrm{~g}$. The provitamin A content of the snacks ranged from $1.29 \mu \mathrm{g} / \mathrm{g}$ to $1.40 \mu \mathrm{g} / \mathrm{g}$ at $0 \%$ Amaranth and $1.54 \mu \mathrm{g} / \mathrm{g}$ to $1.78 \mu \mathrm{g} / \mathrm{g}$ at $3 \%$ Amaranth. The acceptability of the snacks decreased with increasing Amaranth concentration, only a very small proportion (2-8\%) of the panel liked the snacks extremely. PVA maize with added Amaranth leaf powder has a potential for use in nutritious and healthy extruded snacks, but the consumer acceptability of the snacks should be improved.
\end{abstract}

Keywords: under-nutrition; fortification; sensory analysis.

Practical Application: Utilization of low-cost ingredients that consumers are familiar with to enhance the nutritional and health properties of snack foods has a potential for a sustainable health and well-being of targeted consumers.

\section{Introduction}

The number of consumers who are aware of health and wellness related to eating habits is on the rise (Nazzaro et al., 2014; Norazmir et al., 2014; Manzoni et al., 2012; Taverna et al., 2012). Since snacking is an important component of consumers' daily eating and drinking habits (Costa et al., 2010; Datamonitor, 2007), an important market for snacks that fulfil the demands of health-conscious snackers has emerged. The health-conscious consumers are no longer snacking for enjoyment. They demand snacks suitable for specific health needs, such as delivering essential nutrients, improving physical and mental well-being, and prevention of nutrition-related diseases (Norazmir et al., 2014). Therefore, it is crucial for the snack industry to meet the needs of the health-conscious individuals as snacking is projected as long-term trend and a future of eating (Toops, 2012). As a result, it has drawn the attention of most researchers (Duffey et al., 2013). Therefore, there is need for more research on snacks that could provide enjoyment as well as health benefits to the consumers.

Snack foods are favoured across the age spectrum with young women and children being the most dominant serial snackers (Rosenkranz \& Dzewaltowski, 2008). According to studies on consumer trends, more consumers are frequently replacing the traditional three meals a day with snacks (Hirst \& Wohl, 2014). This trend is due, but not limited to, busy lifestyles, increased number of working hours, and more time travelled between home and work (Beswa et al., 2016; Sade \& Aderonke, 2013).

The most consumed snacks are produced from white maize, which is deficient in the essential amino acids lysine and tryptophan (Nuss \& Tanumihardjo, 2011; Świątkiewicz \& Bojanowski, 2004; Shukla \& Cheryan, 2001; Johnson, 2000), provitamin A carotenoids (Menkir et al., 2008), minerals, including zinc and iron (Jin et al., 2013; Tako et al., 2013). Low dietary diversity and a heavy dependency on starchy foods, including white maize, significantly contribute to the prevalence of malnutrition in developing regions, especially in sub-Saharan Africa. Protein and micronutrient (including vitamin A, iron and zinc) deficiencies are particularly prevalent in sub-Saharan Africa. Women, children and the aged are particularly vulnerable to nutrient deficiencies.

- Currently, there are on-going efforts to produce affordable nutritious and healthy snacks by using high nutrient content maize varieties as well as incorporating locally available natural sources of essential nutrients (Beswa et al., 2016; Diaz et al., 2013; Milán-Carrillo et al., 2012; Karkle et al., 2009). Green leafy vegetables, like Amaranth and quinoa leaves, are reported to be good sources of minerals and provitamin A carotenoids (Cardoso et al., 2009; Beswa et al., 2016; Diaz et al., 2013). Amaranthus species are high in vitamins, including $\beta$-carotene, vitamin $B 6$, vitamin $C$, 
riboflavin, folate, as well as essential amino acids and dietary minerals like $\mathrm{Ca}, \mathrm{P}, \mathrm{Fe}, \mathrm{Mg}, \mathrm{K}, \mathrm{Cu}, \mathrm{Zn}$, and $\mathrm{Mn}$ (Mampholo et al., 2015; Venskutonis \& Kraujalis, 2013). The Amaranthus species are well adapted to the sub-Saharan Africa region, where they grow in the wild in abundance. Therefore, incorporating Amaranth leaves in maize-based snacks could improve the nutritive value of the snacks, particularly in terms of improving the essential amino acid profile as well as micronutrient content, including provitamin $\mathrm{A}$, iron and zinc. However, the green pigments and volatile organic compounds present in Amaranth leaves could influence the colour and sensory quality of snacks. On the other hand, yellow/orange provitamin A-bioforfied maize varieties are being evaluated for use to alleviate vitamin A deficiency. Unfortunately, consumers in sub-Saharan Africa who are accustomed to white maize have shown a low preference for the biofortified maize compared to the white maize. The less familiar yellow/orange colour, strong flavour and aroma largely cause the low preference of the biofortified maize (Pillay et al., 2011). Combining provitamin A-biofortified maize with Amaranth leaves in snacks would significantly enhance the nutrient content (including provitamin A) of the snacks and at the same time attenuate the intensities of the green colour of Amaranth leaves and yellow colour and strong flavour and aroma of the provitamin A-biofortified maize. The groups vulnerable to nutrient deficiency in sub-Saharan Africa- children, women and the aged- would be a good target for the provitamin A maize/Amaranth snacks. Thus, the aim of this study was to investigate the effect of Amaranth addition on the nutritional composition and consumer acceptability of the extruded provitamin A-biofortified maize snacks.

\section{Materials and methods}

\subsection{Materials}

The research material consisted of experimental provitamin A-biofortified maize varieties (PVAH1-26, PVAH27-49, PVAH50-75 and PVAH79-100), as well as a white maize variety that was also produced under the same conditions as the experimental varieties. The provitamin A-biofortified maize varieties were produced through conventional breeding methods at Cedara Research Station, Hilton, South Africa. The experimental F1 maize hybrids (varieties) were derived from recombinant inbred lines (hybrid parents) with deep orange grain colour. The F1 hybrids with sufficient seed produced were then planted to produce F2 grain, which was used in the study. A white maize variety was also produced under the same conditions. The fresh leaves of Amaranth (Amaranthus cruentus) were obtained from the A. cruentus plants grown at the Agricultural Research Council Vegetable and Ornamental Plant Institute (ARC-VOPI) in Roodeplaat, South Africa. These plants were grown during the summer months (November-April), with day time temperatures of $25-30^{\circ} \mathrm{C}$, while night temperatures averaged $19-20^{\circ} \mathrm{C}$. Full irrigation was applied during the growing period to have a good stand, avoid flowering and to keep the vegetable quality marketable. The total yields of $A$. cruentus obtained in the 2010/11 and the 2011/12 experiments, ranged between 35 tonnes/hectare and 36 tonnes/hectare on fresh weight basis.

\subsection{Preparation and storage of the maize and Amaranth Leaves}

Maize cobs of the four experimental provitamin A-biofortified maize varieties (PVAH1-26, PVAH27-49, PVAH50-75 and PVAH79-100) and the white variety were harvested manually and dried for 21 days at ambient temperature $\left( \pm 25^{\circ} \mathrm{C}\right)$. The maize cobs were threshed manually and the grain obtained stored at $4{ }^{\circ} \mathrm{C}$ until used. The maize grains were milled whole, while that destined for extrusion was de-germed and milled into a super maize meal fraction using a hammer mill (Model MK 150, Roff Mills, South Africa). The super maize meal was the fraction that passed through the sieve of aperture $495 \mu \mathrm{m}$. Fresh Amaranth leaves were sorted manually, cleaned and then steam blanched at $96^{\circ} \mathrm{C}$ for $4 \mathrm{~min}$, cooled to $-5^{\circ} \mathrm{C}$ and dried at $40{ }^{\circ} \mathrm{C}$ for 3 days using a forced-air oven and stored at $-10^{\circ} \mathrm{C}$ until used. The dried Amaranth leaves were milled using a laboratory hammer mill (Glen Creston, Stanmore, England) fitted with a $1.0 \mathrm{~mm}$ sieve.

\subsection{Methods}

\section{Extrusion}

The de-germed maize flour was partially substituted with dried green Amaranth leaf powder at 0, 1 and 3\% (w/w) levels. The snacks were prepared by extrusion using a Werner and Pfleiderer Continua 37 co-rotating twin-screw extruder (Werner and Pfleiderer Continua, Stuttgart, Germany). Extrusion parameters were kept constant during the processing of the snacks. The barrel temperature was set at $140.7^{\circ} \mathrm{C}$, feed moisture at $20 \%$, screw speed at $400 \mathrm{rpm}$ and a $5-\mathrm{mm}$ restriction die was used. Samples were collected at the die at a temperature around $127^{\circ} \mathrm{C}$. The extrudates were collected into containers, allowed to cool to room temperature and then packaged.

\section{Nutritional analyses}

Proximate analysis of biofortified maize flour and amaranth leaf powder

Moisture, mineral content, fibre, and crude fat content of the milled whole maize flours, amaranth leaf powder and the extrudates were determined using standard methods as described by Beswa et al. (2016). The total non-fibre carbohydrates were determined by difference as described by as follows:

$\%$ Non - fibre carbohydrates $=100-\left(\begin{array}{l}\% \text { Moisture }+ \\ \% \text { Ash }+\% \text { Protein }+ \\ \% \text { Lipids }+ \\ \% \text { Fibre }\end{array}\right)$

Essential amino acids

Essential amino acids were analysed as described by Yan et al. (2015). The method involved hydrolysis of the protein with $\mathrm{HCl}$ and analysis by HPLC. 


\section{Provitamin A content}

The provitamin A content of the maize, extruded snacks and Amaranth leaf powder was determined by HPLC following the method of Kurilich \& Juvik (1999) as modified by Howe \& Tanumihardjo (2006) and Rodriguez-Amaya \& Kimura (2004). In this method, the carotenoids were extracted with methanol and tetrahydrofuran (THF) and then analysed by HPLC. The carotenoids were extracted using the same method for both Amaranth and maize. The total provitamin A concentration was calculated as $\beta$-carotene using the formula (Menkir et al., 2015):

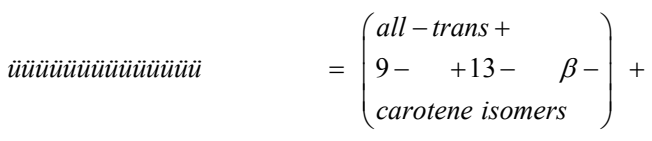

$0.5(\beta-$ cryptoxanthin $)$

\section{Consumer acceptability}

The consumer acceptability of the snacks was evaluated using 50 regular consumers of extruded snacks who were recruited from the Department of Food Science and Technology, University of Venda, South Africa. The consumer panel consisted of 22 males and 28 females with no reported allergies to maize-based diets. The panellists were seated far apart to prevent them from influencing each other. Labelled small disposable plates containing about 20 extruded snacks were randomly presented to the consumer panel. The consumer panel rated the acceptability of the snacks in terms of colour, texture, taste, aroma and overall acceptability using a 5-point facial Hedonic scale, whereby 5 represented the highest score (like extremely) and 1 the lowest score (dislike extremely). Panellists were also provided with tap water to rinse their palates before and between testing.

\section{Statistical analysis}

Two replicate samples of the snacks were produced per variety and the analysis of samples was done in triplicate. The Statistical Package for Social Sciences (SPSS) version 21.0 (SPSS, Chicago, IL, USA) was used to analyse the data. One-way analysis of variance (ANOVA) and Fisher's least significant difference test $(\mathrm{LSD})(\mathrm{P}<0.05)$ were performed to analyse for differences in the nutrient content and consumer acceptability of the snacks.

\section{Results and discussion}

\subsection{Proximate and nutrient composition of raw materials}

The ash content of provitamin A biofortified maize varieties (which ranged from 0.52-0.85 g/100 g) was significantly lower than that of the white maize $(1.02 \mathrm{~g} / 100 \mathrm{~g})$ and Amaranth leaf powder $(10.61 \mathrm{~g} / 100 \mathrm{~g})$ (Table 1$)$. The biofortified maize varieties had lower crude fibre $(8.12-9.86 \mathrm{~g} / 100 \mathrm{~g})$ than white maize $(15.37 \mathrm{~g} / 100 \mathrm{~g})$ and Amaranth leaf powder $(18.11 \mathrm{~g} / 100 \mathrm{~g})$ as well as low fat content (3.50-4.33 g/100 g) compared to white maize $(5.81 \mathrm{~g} / 100 \mathrm{~g})$. The protein content of the biofortified maize varieties (10.17-10.59 g/100 g) and white maize $(10.48 \mathrm{~g} / 100 \mathrm{~g})$ were lower than that of Amaranth leaf powder $(32.51 \mathrm{~g} / 100 \mathrm{~g})$, whilst the biofortified maize varieties had high non-fibre carbohydrate content (66.18-69.05 g/100 g) compared to the white maize (59.26 g/100 g) and Amaranth leaf powder $(28.24 \mathrm{~g} / 100 \mathrm{~g})$. The high ash and protein content of Amaranth leaf powder indicate that Amaranth could enhance the nutritional composition of the extruded provitamin A-biofortified maize snacks with regard to these nutrients.

The different plant organs accumulate varying levels of nutrients. The uptake of mineral nutrients from the soil by maize plants and their distribution have been found to vary with the fertility of the soil, application of fertilizers, the growth stage of the plant and the environmental conditions (Hussaini et al., 2008). There is close relationship between soil moisture and nutrient availability as plants need water for nutrient uptake.

Humans need to consume relatively large amounts of carbohydrates, protein and lipids, and trace amounts of micronutrients like $\mathrm{Fe}$ and $\mathrm{Zn}$. Iron deficiency is among the most widespread nutrient deficiencies and affects over two billion people world-wide (Ortiz-Monasterio et al., 2007). The results of the current study show that biofortification did not increase the ash content of the maize and hence combining the biofortified maize with the Amaranth leafy powder, which was high in minerals, could boost the mineral content of the biofortified maize extruded snacks.

\subsection{Effect of adding Amaranth leaf powder on mineral composition of extruded provitamin A-biofortified maize snacks}

Extrusion cooking is known to improve the nutritional quality of the food, there is good retention of nutrients due to the short residence time of the food material in the barrel as

Table 1. Proximate composition of provitamin A-biofortified maize flour and Amaranth leaf powder (dry weight).

\begin{tabular}{|c|c|c|c|c|c|c|}
\hline Maize variety & $\begin{array}{l}\text { Moisture } \\
(\mathrm{g} / 100 \mathrm{~g})\end{array}$ & $\begin{array}{c}\text { Ash } \\
(\mathrm{g} / 100 \mathrm{~g})\end{array}$ & $\begin{array}{c}\text { Fibre } \\
(\mathrm{g} / 100 \mathrm{~g})\end{array}$ & $\begin{array}{c}\text { Fat } \\
(\mathrm{g} / 100 \mathrm{~g})\end{array}$ & $\begin{array}{c}\text { Protein } \\
(\mathrm{g} / 100 \mathrm{~g})\end{array}$ & $\begin{array}{c}\text { Carbohydrate } \\
(\mathrm{g} / 100 \mathrm{~g})\end{array}$ \\
\hline White maize & $8.06^{\mathrm{c}} \pm 0.14$ & $1.02^{\mathrm{f}} \pm 0.01$ & $15.37^{\mathrm{d}} \pm 0.01$ & $5.81^{\mathrm{f}} \pm 0.01$ & $10.48^{\mathrm{e}} \pm 0.01$ & $59.26^{\mathrm{b}} \pm 0.14$ \\
\hline PVAH79-100 & $9.09^{\mathrm{e}} \pm 0.03$ & $0.66^{\mathrm{b}} \pm 0.01$ & $9.75^{c} \pm 0.03$ & $3.71^{\mathrm{c}} \pm 0.01$ & $10.45^{\mathrm{c}} \pm 0.01$ & $66.34^{c} \pm 0.05$ \\
\hline PVAH1-26 & $9.34^{\mathrm{f}} \pm 0.03$ & $0.52^{\mathrm{a}} \pm 0.01$ & $9.86^{\mathrm{c}} \pm 0.03$ & $3.50^{\mathrm{b}} \pm 0.01$ & $10.59^{\mathrm{d}} \pm 0.01$ & $66.18^{c} \pm 0.05$ \\
\hline PVAH27-49 & $7.28^{\mathrm{a}} \pm 0.27$ & $0.85^{\mathrm{d}} \pm 0.01$ & $8.12^{\mathrm{a}} \pm 0.27$ & $4.33^{\mathrm{e}} \pm 0.01$ & $10.37^{\mathrm{b}} \pm 0.01$ & $69.05^{\mathrm{e}} \pm 0.54$ \\
\hline PVAH50-75 & $8.35^{\mathrm{d}} \pm 0.03$ & $0.71^{c} \pm 0.01$ & $9.06^{\mathrm{b}} \pm 0.02$ & $3.75^{\mathrm{d}} \pm 0.01$ & $10.17^{\mathrm{a}} \pm 0.01$ & $67.95^{\mathrm{d}} \pm 0.03$ \\
\hline Amaranth leaf powder & $7.50^{\mathrm{b}} \pm 0.20$ & $10.61^{\mathrm{e}} \pm 0.01$ & $18.11^{\mathrm{e}} \pm 0.20$ & $3.02^{\mathrm{a}} \pm 0.01$ & $32.51^{\mathrm{f}} \pm 0.01$ & $28.24^{\mathrm{a}} \pm 0.39$ \\
\hline
\end{tabular}

Means \pm SD. Mean values followed by different superscript letters in the same column are significantly different $(p<0.05)$ according to LSD test. PVAH $=$ Provitamin A hybrid. 
well as inactivation of anti-nutritional components (Singh et al., 2007; Razzaq et al., 2012). Ordinary chemical reactions that occur during extrusion cannot cause decomposition or synthesis of nutrients (Singh et al., 2007). Thus, in the current study, extrusion was not expected to significantly cause a change in the nutrient composition in the extruded sacks. However, in the present study, extruded maize snacks had lower fat content than the maize grain (Table 2). The decrease content was probably due to de-germing of maize grain during milling. During maize milling, the fat content of the resultant maize meal is reduced to a minimum in order to increase the shelf-life of the maize meal food products. Fatty foods have a short shelf-life due to deterioration of their fat by lipolysis and oxidation leading to spoilage by rancidity.

Similarly, there was a decrease in the ash content of extruded white maize as well as in the snacks made with provitamin A biofortified maize only (0\% Amaranth leaf powder) (Table 2). As with fat, the observed decrease in ash content was probably due to de-germing of maize grain. It is well-known that in cereal grains, minerals are concentrated in the germ.

However, the addition of Amaranth to pro-vitamin A biofortified maize varieties increased the measured ash content of the extruded snacks, with a significant increase being observed in the snacks made with the biofortified maize variety PVAH 79-100. The initial ash content of PVAH 79-100 was $0.66 \mathrm{~g} / 100 \mathrm{~g}$ for the grain, and increased to $0.70 \mathrm{~g} / 100 \mathrm{~g}$ at $1 \%$ Amaranth concentration, and further increased to $0.81 \mathrm{~g} / 100 \mathrm{~g}$ when Amaranth concentration was 3\%. All the four biofortified maize varieties showed an increase in ash content when Amaranth leaf powder was increased to $3 \%$.

The Zinc content was observed to generally decrease with extrusion, and the addition of Amaranth leaf powder did not have any significant impact (Table 2). The decrease in measured zinc content on extrusion can be attributed to de-germing of the maize grain as already explained.

Extrusion and increasing the concentration of Amaranth leaf powder resulted in an increase of the iron content of the biofortified maize snacks. The iron content of the snacks increased even before addition of Amaranth leaf powder, for example from a range of $8.33 \mathrm{mg} / \mathrm{kg}$ and $11.33 \mathrm{mg} / \mathrm{kg}$ to a range of $115.0 \mathrm{mg} / \mathrm{kg}$ to $118 \mathrm{mg} / \mathrm{kg}$, representing an iron increase of over $900 \%$. The observed increase in iron content cannot only be attributed to the contribution of Amaranth leaf powder, which contained an average iron content of $971 \mathrm{mg} / \mathrm{kg}$. Similar to the suggestion by other workers, the excess iron, especially in the extruded maize without Amaranth powder could have be from the wear and tear of metallic pieces, mainly screws of the extruder (Singh et al., 2007).

These results indicate that Amaranth leaf powder has a good potential to make significant contribution to improved mineral content of the extruded snacks and thereby alleviate mineral deficiencies that are predominant in sub-Saharan Africa. The results confirm what is documented in the literature that Amaranth leaves and grains are nutritionally superior to cereal grains (Venskutonis \& Kraujalis, 2013; Escudero et al., 1999; Makobo et al., 2010).

Table 2. Fibre, fat and mineral composition of provitamin A-biofortified maize grain, Amaranth leaf powder and extruded snacks, DW.

\begin{tabular}{|c|c|c|c|c|c|c|c|}
\hline $\begin{array}{c}\text { Maize variety } \\
\text { and Amaranth }\end{array}$ & $\begin{array}{c}\text { Amaranth } \\
\text { concentration }\end{array}$ & $\begin{array}{c}\text { Ash } \\
\mathrm{g} / 100 \mathrm{~g}\end{array}$ & $\begin{array}{c}\text { Fat } \\
\mathrm{g} / 100 \mathrm{~g}\end{array}$ & $\begin{array}{c}\text { ADF } \\
\mathrm{g} / 100 \mathrm{~g}\end{array}$ & $\begin{array}{c}\text { NDF } \\
\mathrm{g} / 100 \mathrm{~g}\end{array}$ & $\begin{array}{c}\mathrm{Zn} \\
\mathrm{mg} / \mathrm{kg}\end{array}$ & $\begin{array}{c}\mathrm{Fe} \\
\mathrm{mg} / \mathrm{kg}\end{array}$ \\
\hline \multirow{2}{*}{ White maize } & Grain & $1.02^{\mathrm{j}} \pm 0.01$ & $5.81^{\mathrm{k}} \pm 0.01$ & $4.90^{\mathrm{de}} \pm 0.01$ & $10.46^{\mathrm{f}} \pm 0.01$ & $26.33^{e} \pm 0.58$ & $20.67^{b} \pm 0.58$ \\
\hline & $0 \%$ & $0.40^{\mathrm{a}} \pm 0.04$ & $0.04^{a} \pm 0.02$ & $2.36^{\mathrm{a}} \pm 0.04$ & $4.53^{c} \pm 0.15$ & $25.00^{e} \pm 2.65$ & $120.00^{e} \pm 2.65$ \\
\hline \multirow{2}{*}{ PVAH79-100 } & $0 \%$ & $0.55^{\mathrm{cd}} \pm 0.05$ & $0.44^{\mathrm{d}} \pm 0.06$ & $2.96^{\mathrm{b}} \pm 0.04$ & $17.18^{\mathrm{h}} \pm 0.58$ & $25.00^{\mathrm{e}} \pm 1.73$ & $115.67^{\mathrm{de}} \pm 4.93$ \\
\hline & $1 \%$ & $0.70^{\mathrm{efg}} \pm 0.03$ & $0.06^{a} \pm 0.03$ & $1.89^{\mathrm{a}} \pm 0.12$ & $4.51^{c} \pm 0.18$ & $21.00^{\mathrm{cd}} \pm 2.65$ & $155.33^{\mathrm{f}} \pm 5.51$ \\
\hline \multirow{3}{*}{ PVAH1-26 } & $0 \%$ & $0.58^{\text {cde }} \pm 0.02$ & $0.46^{\mathrm{d}} \pm 0.01$ & $3.36^{b} \pm 0.23$ & $17.12^{\mathrm{h}} \pm 0.57$ & $26.33^{\mathrm{e}} \pm 1.53$ & $118.33^{\mathrm{de}} \pm 1.53$ \\
\hline & $1 \%$ & $0.42^{\mathrm{ab}} \pm 0.04$ & $0.13^{\mathrm{b}} \pm 0.03$ & $2.16^{\mathrm{a}} \pm 0.52$ & $1.56^{\mathrm{a}} \pm 0.12$ & $17.33^{b} \pm 1.53$ & $67.33^{c} \pm 3.79$ \\
\hline & $3 \%$ & $0.65^{\mathrm{def}} \pm 0.08$ & $0.45^{\mathrm{d}} \pm 0.07$ & $3.88^{c} \pm 0.34$ & $6.75^{\mathrm{d}} \pm 0.26$ & $10.67^{\mathrm{a}} \pm 1.53$ & $117.67^{\mathrm{de}} \pm 3.21$ \\
\hline \multirow{2}{*}{ PVAH27-49 } & Grain & $0.85^{\mathrm{hi}} \pm 0.01$ & $4.33^{j} \pm 0.01$ & $6.20^{f} \pm 0.00$ & $11.40^{\mathrm{g}} \pm 0.00$ & $23.67^{\mathrm{de}} \pm 0.58$ & $11.33^{\mathrm{a}} \pm 0.58$ \\
\hline & $0 \%$ & $0.58^{\text {cde }} \pm 0.03$ & $0.44^{\mathrm{d}} \pm 0.03$ & $3.08^{\mathrm{b}} \pm 0.21$ & $17.12^{\mathrm{h}} \pm 0.34$ & $24.67^{\mathrm{e}} \pm 1.53$ & $115.00^{\mathrm{de}} \pm 2.65$ \\
\hline \multirow{2}{*}{ PVAH50-75 } & $1 \%$ & $1.26^{\mathrm{k}} \pm 0.03$ & $0.53^{\mathrm{e}} \pm 0.04$ & $4.58^{\mathrm{d}} \pm 0.76$ & $3.52^{\mathrm{b}} \pm 0.22$ & $23.00^{\mathrm{de}} \pm 2.65$ & $240.00^{\mathrm{i}} \pm 4.36$ \\
\hline & $3 \%$ & $0.89^{\mathrm{i}} \pm 0.11$ & $0.29^{c} \pm 0.03$ & $5.29^{\mathrm{e}} \pm 0.15$ & $6.52^{\mathrm{d}} \pm 0.31$ & $21.33^{\mathrm{cd}} \pm 2.08$ & $179.33^{g} \pm 4.62$ \\
\hline $\begin{array}{l}\text { Amaranth leaf } \\
\text { powder }\end{array}$ & & $10.57^{1} \pm 0.05$ & $3.03^{g} \pm 0.02$ & $16.73^{g} \pm 0.02$ & $19.88^{\mathrm{i}} \pm 0.08$ & $31.33^{\mathrm{f}} \pm 2.08$ & $971.67^{\mathrm{k}} \pm 2.31$ \\
\hline
\end{tabular}

Means \pm SD. Mean values followed by different superscript letters in the same column are significantly different $(p<0.05)$ according to LSD test. PVAH $=$ Provitamin A hybrid; DW $=$ dry weight basis. 


\subsection{Effect of adding Amaranth leaf powder on protein content and essential amino acid composition of extruded provitamin A-biofortified maize snacks}

The protein content of the white and biofortified maize grains were in the range of 10.1-10.59 g/100 g, with the provitamin A biofortified maize variety, PVAH50-75 having the lowest protein content $(10.17 \mathrm{~g} / 100 \mathrm{~g})$, whilst the biofortified maize variety, PVAH1-26 had the highest protein content (10.59 g/100 g) (Table 3). As expected, the extrudates with $0 \%$ Amaranth had lower protein content than the grain, because of the degerming process in the preparation of the flour for extrusion. The provitamin A-biofortified maize extrudates had higher protein content than the white maize variety $(8.2-10.7 \mathrm{~g} / 100 \mathrm{~g}$ and $7.5 \mathrm{~g} / 100 \mathrm{~g}$, respectively). Similarly, the essential amino acid content of the extrudates produced using biofortified maize varieties was higher than that of the white maize variety, for example lysine content of biofortified maize extrudates with $0 \%$ Amaranth, was an average $0.1 \mathrm{~g} / 100 \mathrm{~g}$, when compared with the lysine content of the extruded white maize variety $(0.06 \mathrm{~g} / 100 \mathrm{~g})$. The incorporation of Amaranth leaf powder increased lysine content, and the highest observation was in the biofortified maize variety, PVAH50-75 extrudates containing 3\% Amaranth which had lysine content of $0.17 \mathrm{~g} / 100 \mathrm{~g}$. The general trend was that the biofortified maize flour had higher protein and essential amino acid lysine, when compared with the snacks without Amaranth leaf powder ( $0 \%$ Amaranth leaf powder). This decrease in protein was probably due to de-germing of the maize grain, because the germ contains a significant amount of protein. It is also possible that thermal degradation of the protein could have also occurred since it is known that ammonia is emitted when $\mathcal{E}$-amine group of lysine react with the amide group of asparagines or glutamine (Sobota \& Rzedzicki, 2009). A decrease in lysine content is an indicator of the extent of protein degradation during thermal processing (Singh et al., 2007). In this study, the lysine content of the maize flour ranged from 0.19 to $0.26 \mathrm{~g} / 100 \mathrm{~g}$ (dry weight), which was significantly higher than that of the extruded snacks (0.10-0.13 g/100 g dry weight) at 0\% Amaranth leaf powder concentration.

The addition of Amaranth leaf powder seems to have positively influenced the protein content of the extruded snacks. However, there was no clear trend observed on the influence of Amaranth leaf powder concentration on the protein content of the snacks. The protein content of snacks made with PVAH 1-26 was $9.12 \mathrm{~g} / 100 \mathrm{~g}$ at $0 \%$ Amaranth leaf powder concentration. The addition of Amaranth leaf powder (1\%) resulted in a decrease in the protein content of these snacks $(8.24 \mathrm{~g} / 100 \mathrm{~g})$. As the Amaranth leaf powder concentration increased to $3 \%$, the protein content of snacks made with PVAH 1-26 increased significantly $(9.13 \mathrm{~g} / 100 \mathrm{~g})$. An opposite trend was observed for snacks made with PVAH 27-49 where a decrease in protein content of the snacks was recorded at 3\% Amaranth leaf powder concentration, whilst the protein content of snacks made with PVAH 50-75 and PVAH 79-100 increased with increased concentration of Amaranth leaf powder. The changes in protein content of the snacks made with PVAH 1-26 and PVAH 27-49 were similar to changes in methionine and phenylalanine contents of snacks made with biofortified varieties.
As stated earlier, Amaranth leaf powder was higher in protein and essential amino acids than both the biofortified maize varieties and the white variety. As a rich source of nutrients (including protein and essential amino acids) (Venskutonis \& Kraujalis, 2013; Alegbejo, 2013), Amaranth leaf powder would improve the nutrient content of food it is added to, such as snacks (Chavez-Jauregui et al., 2003).

\subsection{Effect of Amaranth leaf powder addition on measurable provitamin A of extruded biofortified maize snacks}

The provitamin A carotenoid content of biofortified maize flour, white maize (control), extruded maize snacks and Amaranth leaf powder is presented in Table 4 . The white maize flour and extrudates did not contain $\beta$-carotene or any type of provitamin A carotenoids, since none were detected. The Amaranth leaf powder had relatively higher total provitamin A carotenoid content $(9.6 \mathrm{mg} / 100 \mathrm{~g}$ or $96 \mu \mathrm{g} / \mathrm{g})$ than maize flours of the biofortified maize varieties (ranges were between 2.41 and $2.59 \mu \mathrm{g} / \mathrm{g}$ or $0.24-0.26 \mathrm{mg} / 100 \mathrm{~g}$ ). The all trans- $\beta$-carotene content of Amaranth leaf powder $(68.8 \mu \mathrm{g} / \mathrm{g}$ or $6.9 \mathrm{mg} / 100 \mathrm{~g})$ was more than $82 \%$ higher than that of biofortified maize varieties (ranges were 0.83 to $0.86 \mu \mathrm{g} / \mathrm{g}$ or $0.08-0.09 \mathrm{mg} / 100 \mathrm{~g}$ ). Amaranth leaf powder was high in all carotenoids and provitamin A contents except for $\beta$-cryptoxanthin. Significantly higher $\beta$-carotene content $(28.5 \mathrm{mg} / 100 \mathrm{~g})$ in Amaranth leaves was also reported by Dlamini et al. (2010). The carotenoid content of extruded snacks with $0 \%$ Amaranth leaf powder was lower compared to that of the biofortified maize flour. The decrease in carotenoid content on extrusion could probably be due to thermal degradation of the carotenoids pigments which are known to be heat-sensitive. The carotenoid content of the snacks increased as the concentration of Amaranth leaf powder increased. The increase in $\beta$-carotene ranged from 34.7 to $66.7 \%$ relative to snacks with $0 \%$ Amaranth leaf powder. The $\beta$-carotene isomers 9-cis- $\beta$-carotene increased by $5.3-13.9 \%, 13$-cis- $\beta$-carotene by $12-19.4 \%$, $\beta$-cryptoxanthin by $9.8-48.7 \%$, whilst the total provitamin A content increased by $18-32.6 \%$ (Table 4 ).

The increase in provitamin A carotenoid content of the snacks with increasing Amaranth leafy powder indicates that the leaf powder significantly influenced the final content of provitamin A carotenoids in the extruded snacks. The Amaranth leaf powder contributed a significant proportion of total provitamin A content of the snacks and therefore it would be an essential component of extruded maize snacks for use in addressing vitamin A deficiency.

\subsection{Effect of Amaranth leaf powder addition on consumer acceptability of extruded provitamin A-biofortified maize snacks}

The sensory quality of food is of prime importance as it affects its consumer acceptability. The effect of Amaranth leaf powder addition on consumer acceptability of the snacks is shown in Table 5. As Amaranth leaf powder concentration increased, the colour and appearance of the snacks were extremely disliked by $4-12 \%$ and $0-20 \%$ of the consumer panel, respectively, whilst $2-24 \%$ and $6-18 \%$ of the consumer panel extremely liked the 
Beswa et al.

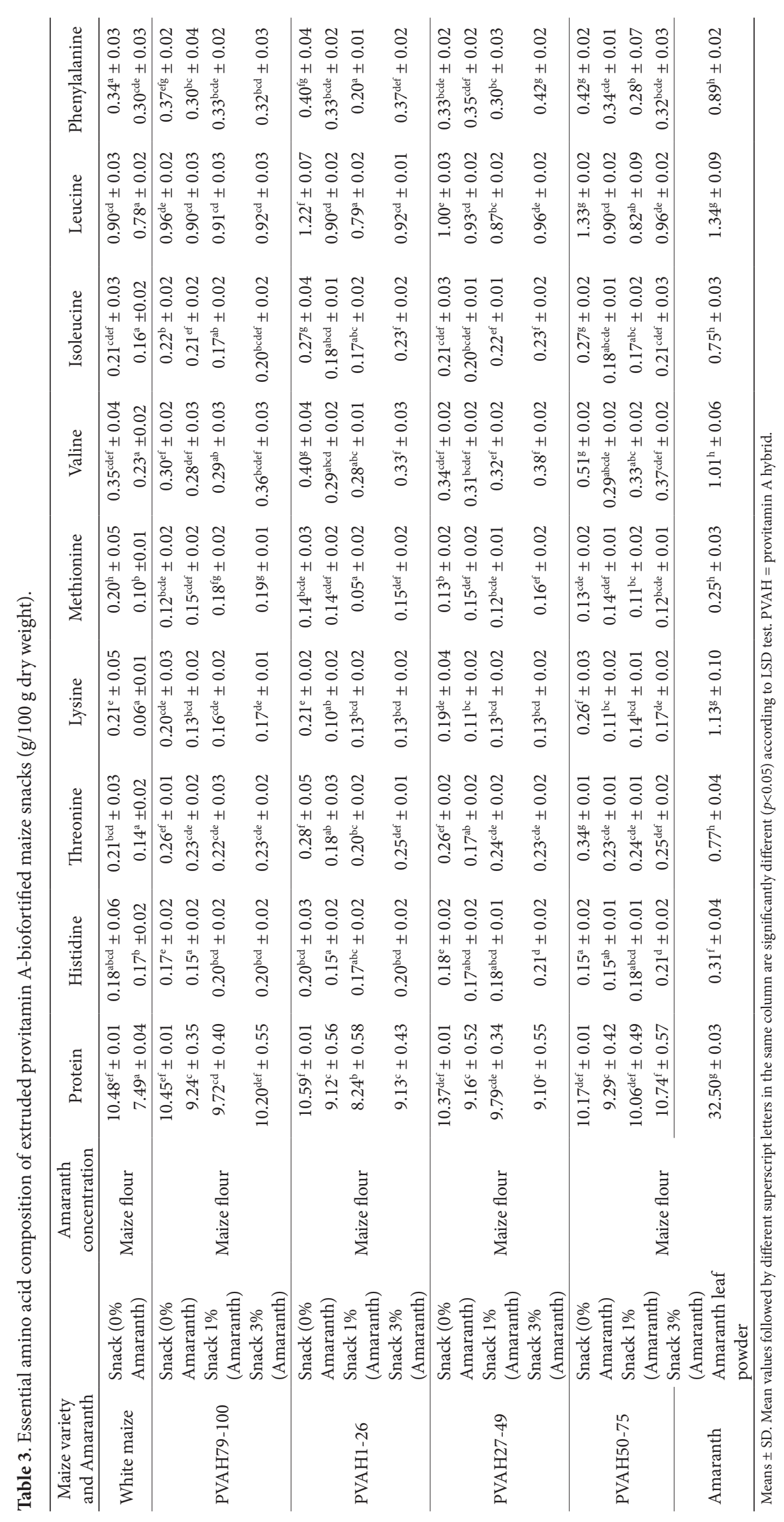


Table 4. Provitamin A carotenoids composition of maize grain and Amaranth leaf powder ( $\mu \mathrm{g} / \mathrm{g}$ dry weight).

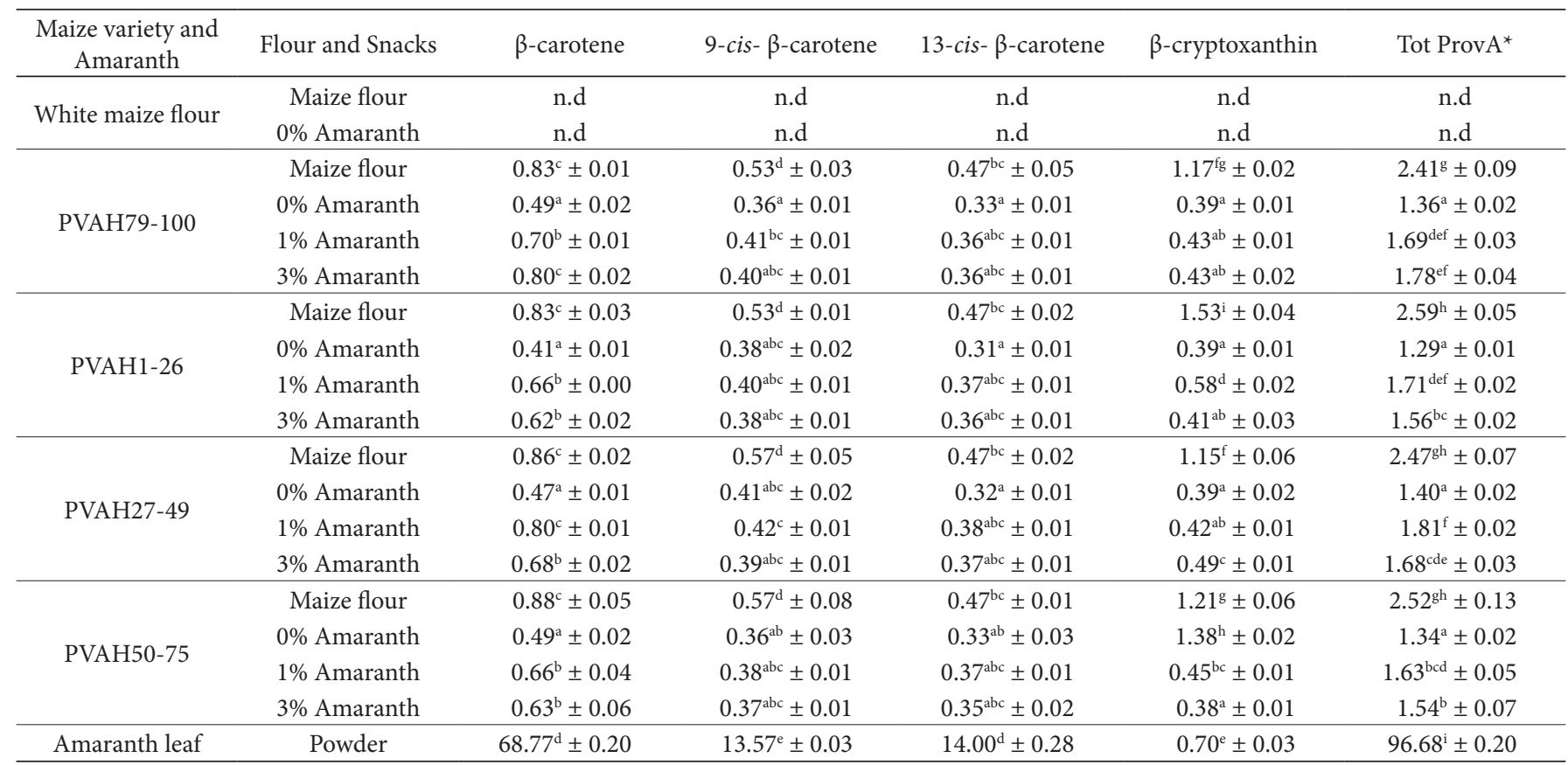

${ }^{*}$ Total provitamin $\mathrm{A}=$ (all-trans+9-cis+13-cis $\beta$-carotene isomers) +0.5 ( $\beta$-cryptoxanthin). Means $\pm \mathrm{SD}$. Mean values followed by different superscript letters in the same column are significantly different $(p<0.05)$ according to LSD test. $\mathrm{n} . \mathrm{d}=$ not detected, $\mathrm{PVAH}=$ provitamin $\mathrm{A}$ hybrid.

Table 5. Percentage of panellists who gave the different ratings for the evaluated sensory attributes $(n=50)$.

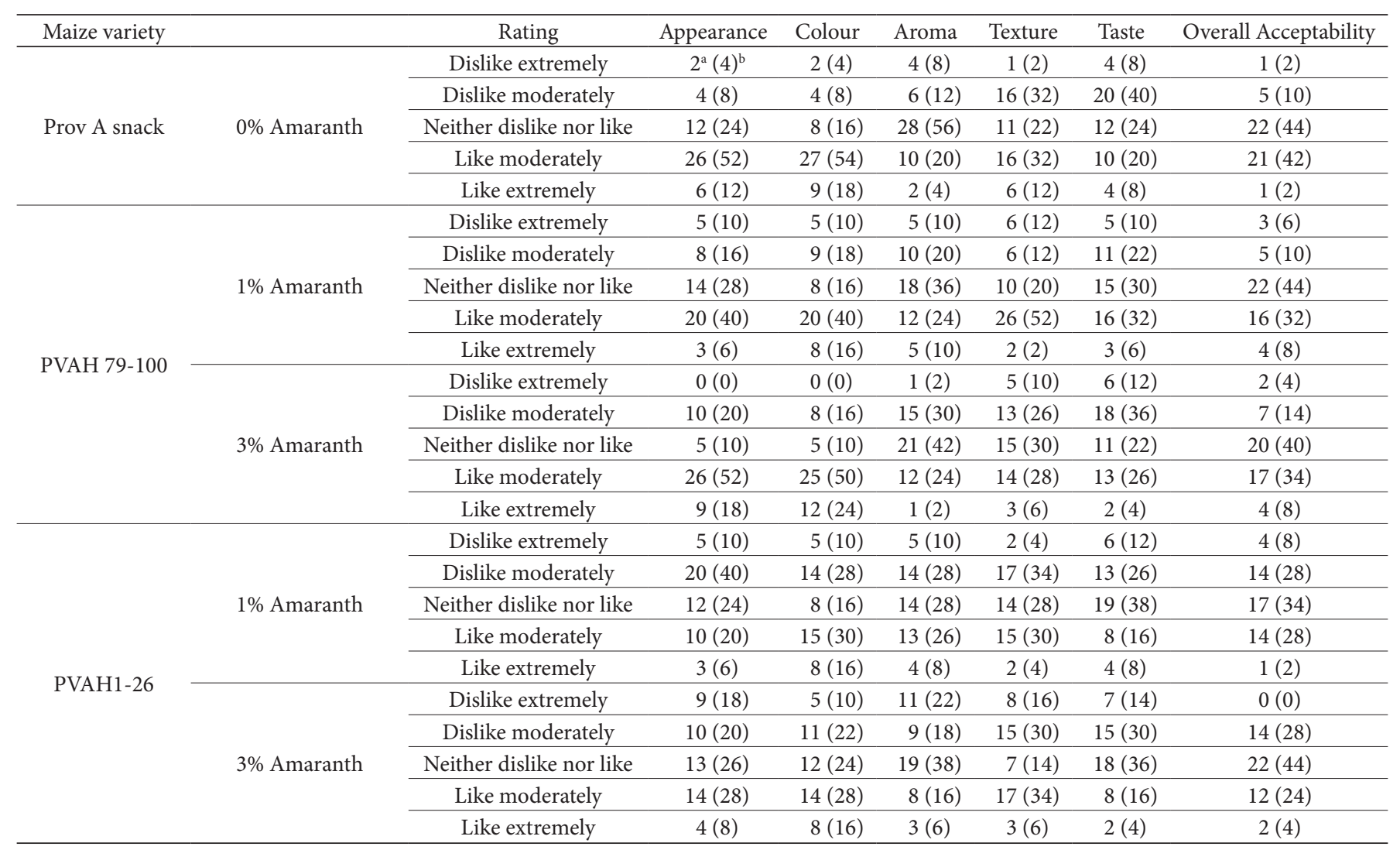

${ }^{a}$ Number of subjects. ${ }^{\mathrm{b}}$ Percentage of total number of participants; $\mathrm{PVAH}=$ provitamin $\mathrm{A}$ hybrid. 
Table 5. Continued...

\begin{tabular}{|c|c|c|c|c|c|c|c|c|}
\hline Maize variety & & Rating & Appearance & Colour & Aroma & Texture & Taste & Overall Acceptability \\
\hline \multirow{8}{*}{ PVAH27-49 } & \multirow{5}{*}{ 1\% Amaranth } & Dislike extremely & $4(8)$ & $4(8)$ & $3(6)$ & $9(18)$ & $9(18)$ & $1(2)$ \\
\hline & & Dislike moderately & $9(18)$ & $13(26)$ & $18(36)$ & $16(32)$ & $15(30)$ & $14(28)$ \\
\hline & & Neither dislike nor like & $18(36)$ & $14(28)$ & $13(26)$ & $5(10)$ & $15(30)$ & $16(32)$ \\
\hline & & Like moderately & $16(32)$ & $18(36)$ & $8(16)$ & $15(30)$ & $4(8)$ & $15(30)$ \\
\hline & & Like extremely & $3(6)$ & $1(2)$ & $8(16)$ & $5(10)$ & $7(14)$ & $4(8)$ \\
\hline & \multirow{3}{*}{$3 \%$ Amaranth } & Dislike extremely & $5(10)$ & $6(12)$ & $5(10)$ & $8(16)$ & $6(12)$ & $2(4)$ \\
\hline & & Like moderately & $17(34)$ & $12(24)$ & $12(24)$ & $16(32)$ & $9(18)$ & $16(32)$ \\
\hline & & Like extremely & $7(14)$ & $7(14)$ & $5(10)$ & $5(10)$ & $5(10)$ & $1(2)$ \\
\hline \multirow{7}{*}{ PVAH50-75 } & \multirow[b]{3}{*}{ 1\% Amaranth } & Dislike extremely & $4(8)$ & $2(4)$ & $8(16)$ & $5(10)$ & $11(22)$ & $1(2)$ \\
\hline & & Dislike moderately & $9(18)$ & $15(30)$ & $10(20)$ & $11(22)$ & $14(28)$ & $11(22)$ \\
\hline & & Neither dislike nor like & $17(34)$ & $12(24)$ & $19(38)$ & $16(32)$ & $17(34)$ & $18(36)$ \\
\hline & \multirow{4}{*}{$3 \%$ Amaranth } & Dislike moderately & $8(16)$ & $7(14)$ & $10(20)$ & $10(20)$ & $14(28)$ & $10(20)$ \\
\hline & & Neither dislike nor like & $7(14)$ & $12(24)$ & $17(34)$ & $14(28)$ & $14(28)$ & $22(44)$ \\
\hline & & Like moderately & $18(36)$ & $19(38)$ & $16(32)$ & $18(36)$ & $14(28)$ & $13(26)$ \\
\hline & & Like extremely & $7(14)$ & $6(6)$ & $2(4)$ & $4(8)$ & $6(12)$ & $4(8)$ \\
\hline
\end{tabular}

${ }^{a}$ Number of subjects. ${ }^{b}$ Percentage of total number of participants; PVAH = provitamin A hybrid.

colour and appearance, respectively. It appears that green pigments from Amaranth leaf powder had no negative effect on the liking of snacks colour. This is a significant observation as the colour holds a prime role in consumer appeal of food products. The texture and taste of the snacks were extremely disliked by $2-18 \%$ and $4-22 \%$ of consumer panel, respectively, whilst $2-14 \%$ and $6-12 \%$ of the panel extremely liked their texture and taste, respectively. The low percentage of panellists who liked the texture was probably due to intense hardness of the snacks. The texture of extruded snacks is considered a most significant sensory attribute as it controls the snacksrelated eating sounds. These sonic-textural properties of extruded snacks are desirable to consumers and therefore, any difficulties in fracturing of snacks would negatively affect the liking of the snacks. Whilst low percentage of panellists who disliked taste can be linked to undesirable aftertaste imparted by phenolic compounds (Dykes \& Rooney, 2007). Food taste has is known to influence the consumer choice of food (Jezewska-Zychowicz \& Krolak, 2015).

Overall, the snacks were disliked extremely by $0-8 \%$ of consumers, disliked moderately by $10-28 \%$, whilst 32 $44 \%$ neither disliked nor liked them. About $24-32 \%$ of the consumer panel moderately liked the snacks, whilst $2-8 \%$ extremely liked the snacks. Sensory attributes such as colour, taste, texture and appearance are some of the key sensory qualities that contribute to consumer acceptance of snacks. The notable proportions of the consumer panel which extremely disliked these sensory attributes indicate that there is a need to improve these sensory attributes to increase the acceptance of the snacks. Further recipe development could improve the sensory properties of the snacks. Consumers are becoming more health-conscious and as more consumers are continuously searching for diets which can positively impact on their health, there is more interest in foods with documented health benefits (Ahmed \& Abozed, 2015; Ying \& Gantenbein-Demarchi, 2013; Taverna et al., 2012). On the other hand, some consumers are unwilling to try novel food products. For example, consumption of insect carrier foods is associated with primitive lifestyle. However, according to Gaviria \& Bluemelhuber (2010) consumer behaviour evolves over time; therefore the repeated exposure increases the chance of product liking. Also, the consumer perceptions change as they become aware of health benefits associated the new food product (Jezewska-Zychowicz \& Krolak, 2015). Therefore, education about the nutritional contribution and health benefits of provitamin A-biofortified maize varieties and Amaranth leaf powder in extruded snacks could contribute to an increase in the overall acceptability of the snacks, especially to consumers falling in the undecided cluster.

\section{Conclusion}

The addition of Amaranth leaf powder to the extruded provitamin A-biofortified maize snacks had a significant effect on their quality attributes. The nutrient content (including essential amino acids, provitamin $\mathrm{A}$ and $\mathrm{Fe}$ ) of the snacks was significantly improved by the addition of Amaranth leaf powder. The snacks made with the biofortified varieties had high protein and mineral content. However, there is a need to improve the sensory quality of Amaranth-enriched snacks through education of consumers about the role of Amaranth on nutrition and health-promoting benefits of the snacks. 


\section{Acknowledgements}

Financial support by the University of Venda, University of KwaZulu-Natal and National Research Foundation (NRF, South Africa) is acknowledged. We also thank the CSIR (South Africa) Biosciences for the use of the pilot plant food-processing facilities and analytical laboratories, as well as ARC (South Africa) for providing the amaranth and the Department of Science and Technology (DST) (South Africa) for funding the cultivation of Amaranth

\section{References}

Ahmed, Z. S., \& Abozed, S. S. (2015). Functional and antioxidant properties of novel snack crackers incorporated with Hibiscus sabdariffa by-product. Journal of Advanced Research, 6(1), 79-87. http://dx.doi.org/10.1016/j.jare.2014.07.002. PMid:25685546.

Alegbejo, J. O. (2013). Nutritional value and utilization of Amaranth (Amaranthus spp): a review. Bayero Journal of Pure and Applied Sciences, 6(1), 136-143.

Beswa, D., Dlamini, N. R., Amonsou, E. O., Siwela, M., \& Derera, J. (2016). Effects of amaranth addition on the provitamin A content, and physical and antioxidant properties of extruded provitamin A-biofortified maize snacks. Journal of the Science of Food and Agriculture, 96(1), 287-294. http://dx.doi.org/10.1002/jsfa.7092. PMid:25641316.

Cardoso, P. C., Lucia, C. M. D., Stringheta, P. C., Chaves, J. B. P., \& Pinheiro-Sant'Ana, H. M. (2009). Carotene and provitamin A content of vegetables sold in Viçosa, MG, Brazil, during spring and winter. Brazilian Journal of Pharmaceutical Sciences, 45(3), 527-537. http:// dx.doi.org/10.1590/S1984-82502009000300019.

Chavez-Jauregui, R. N., Cardoso-Santiago, R. A., Silva, M. E. M. P., \& Areas, J. A. G. (2003). Acceptability of snacks produced by the extrusion of Amaranth and blends of chickpea and bovine lung. International Journal of Food Science \& Technology, 38(7), 795-798. http://dx.doi.org/10.1046/j.1365-2621.2003.00734.x.

Costa, P. F. P., Ferraz, M. B. M., Ros-Polski, V., Quast, E., Collares Queiroz, F. P., \& Steel, C. J. (2010). Functional extruded snacks with lycopene and soy protein. Ciência e Tecnologia de Alimentos. In press.

Datamonitor. (2007). Healthy snacking: future trends and new insights. London. Retrieved from http://www.datamonitor.com/consumer

Diaz, J. M. R., Kirjoranta, S., Tenitz, S., Penttilä, P. A., Serimaa, R., Lampi, A. M., \& Jouppila, K. (2013). Use of amaranth, quinoa and kañiwa in extruded corn-based snacks. Journal of Cereal Science, 58(1), 59-67. http://dx.doi.org/10.1016/j.jcs.2013.04.003.

Dlamini, N. R., Moroka, T., Mlotshwa, L., Reddy, J., \& Botha, G. (2010). Indigenous edible plants as sources of nutrients and health benefitting components (nutraceuticals). South African: CSIR Researchspace. Retrieved from http://researchspace.csir.co.za/ dspace/handle/10204/4224? mode=full

Duffey, K. J., Pereira, R. A., \& Popkin, B. M. (2013). Prevalence and energy intake from snacking in Brazil: analysis of the first nationwide individual survey. European Journal of Clinical Nutrition, 67(8), 868-874. http://dx.doi.org/10.1038/ejcn.2013.60. PMid:23486510.

Dykes, L., \& Rooney, L. W. (2007). Phenolic compounds in cereal grains and their health benefits. Cereal Foods World, 52 105-111.

Escudero, N. L., Albarracin, G., Fernandez, S., Arellano, L. M., \& Mucciarelli, S. (1999). Nutrient and antinutrient composition of Amaranthus muricatus. Plant Foods for Human Nutrition, 54(4), $327-$ 336. http://dx.doi.org/10.1023/A:1008149721435. PMid:10798343.
Gaviria, P. R., \& Bluemelhuber, C. (2010). Consumers' transformations in a liquid society: introducing the concepts of autobiographicalconcern and desire-assemblage. Journal of Consumer Behaviour, 9(2), 126-138. http://dx.doi.org/10.1002/cb.309.

Hirst, E. J., \& Wohl, J. (2014). Nation of nibblers: snacks replace meals for rising number offolks. Chicago: Chicago Tribune. Retrieved from http://articles.chicagotribune.com/2014-02-23/site/ct-snackingall-day-0223-biz-20140223_1_meals-mindless-munching-oreos

Howe, J. A., \& Tanumihardjo, S. A. (2006). Evaluation of analytical methods for carotenoid extraction from biofortified maize (Zea mays). Journal of Agricultural and Food Chemistry, 54(21), 79927997. http://dx.doi.org/10.1021/jf062256f. PMid:17032000.

Hussaini, M. A., Ogunlela, V. B., Ramalan, A. A., \& Falaki, A. M. (2008). Mineral composition of dry season maize (Zea Mays L.) in response to varying levels of nitrogen, phosphorus and irrigation at Kadawa, Nigeria. World Journal of Agricultural Sciences, 4(6), 775-780.

Jezewska-Zychowicz, M., \& Krolak, M. (2015). Do consumers' attitude towards food technologies and motives of food choices influence willingness to eat cerealproducts fortified with fibre. Polish Journal of Food Nutrition \& Science, 65(4), 281-292. http://dx.doi.org/10.2478/ pjfns-2013-0014.

Jin, T., Zhou, J., Chen, J., Zhu, L., Zhao, Y., \& Huang, Y. (2013). The genetic architecture of zinc and iron content in maize grains as revealed by QTL mapping and meta-analysis. Breeding Science, 63(3), 317-324. http://dx.doi.org/10.1270/jsbbs.63.317. PMid:24273427.

Johnson, L. A. (2000). Corn: the major cereals of the Americas. In K. Kulp \& J. G. Ponte (Eds.), Handbook of cereal science and technology (2nd ed., pp. 38). New York: Dekker.

Karkle, E. L., Jain, S., Waghray, K., Alavi, S., \& Dogan, H. (2009). Development and evaluation of fruit and vegetable-based extruded snacks. In Proceedings of the American Association of Cereal Chemists Annual Meeting, Honolulu, HI.

Kurilich, A. C., \& Juvik, J. A. (1999). Quantification of carotenoid and tocopherol antioxidants in Zea mays. Journal of Agricultural and Food Chemistry, 47(5), 1948-1955. http://dx.doi.org/10.1021/ jf981029d. PMid:10552476.

Makobo, N. D., Shoko, M. D., \& Mtaita, T. A. (2010). Nutrient content of Amaranth (Amaranthus cruentus L.) under different processing and preservation methods. World Journal of Agricultural Sciences, 6(6), 639-643.

Mampholo, M. B., Sivakumar, D., \& Van Rensburg, J. (2015). Variation in bioactive compounds and quality parameters in different modified atmosphere packaging during postharvest storage of traditional leafy vegetables (Amaranthus cruentus L and Solanum retroflexum). Journal of Food Quality, 38(1), 1-12. http://dx.doi.org/10.1111/jfq.12120.

Manzoni, M. S. J., Cavallini, D. C. U., Pauly-Silveira, N. D., Roselino, M. N., \& Rossi, E. A. (2012). Development of a synbiotic low-calorie beverage made from soy and yacon extracts. Food and Nutrition Sciences, 3(11), 1500-1508. http://dx.doi.org/10.4236/fns.2012.311195.

Menkir, A., Liu, W., White, W. S., Maziya-Dixon, B., \& Rocheford, T. (2008). Carotenoid diversity in tropical-adapted yellow maize inbred lines. Food Chemistry, 109(3), 521-529. http://dx.doi.org/10.1016/j. foodchem.2008.01.002.

Menkir, A., Rocheford, T., Maziya-Dixon, B., \& Tanumihardjo, S. A. (2015). Exploiting natural variation in exotic germplasm for increasing provitamin A carotenoids in tropical maize. Euphytica, 1-5. http://dx.doi.org/10.1007/s10681-015-1426-z.

Milán-Carrillo, J., Montoya-Rodríguez, A., Gutiérrez-Dorado, R., Perales-Sánchez, X., \& Reyes-Moreno, C. (2012). Optimization of extrusion process for producing high antioxidant instant Amaranth 
(Amaranthus hypochondriacus L.) flour using Response Surface Methodology. Applied Mathematics, 3(10), 1516-1525. http://dx.doi. org/10.4236/am.2012.330211.

Nazzaro, F., Cardinale, F., Cozzolino, A., Granese, T., \& Fratianni, F. (2014). Polyphenol composition and antioxidant activity of different potentially functional kale-based snacks. Food and Nutrition Sciences, 5(12), 1145-1152. http://dx.doi.org/10.4236/fns.2014.512124.

Norazmir, M., Mastura, K., Bariah, A., Devi, M., \& Sabariah, B. (2014). Development of whole grain carrot (DaucusCarota) chips. Current Research in Nutrition and Food Science, 2(1), 26-32. http://dx.doi. org/10.12944/CRNFSJ.2.1.04.

Nuss, E. T., \& Tanumihardjo, S. A. (2011). Quality protein maize for Africa: Closing the protein inadequacy gap in vulnerable populations. Advances in Nutrition, 2(3), 217-224. http://dx.doi.org/10.3945/ an.110.000182. PMid:22332054

Ortiz-Monasterio, J. I., Palacios-Rojas, N., Meng, E., Pixley, K., Trethowan, R., \& Pena, R. J. (2007). Enhancing the mineral and vitamin content of wheat and maize through plant breeding. Journal of Cereal Science, 46(3), 293-307. http://dx.doi.org/10.1016/j.jcs.2007.06.005.

Pillay, K., Derera, J., Siwela, M., \& Veldman, F. J. (2011). Consumer acceptance of yellow, provitamin A-biofortified maize in KwaZuluNatal. The South African Journal of Clinical Nutrition, 24(4), 186-191.

Razzaq, M. R., Anjum, F. M., Khan, M. I., Khan, M. R., Nadeem, M., Javed, M. S., \& Sajid, M. W. (2012). Effect of temperature, screw speed and moisture variations on extrusion cooking behavior of maize (Zea mays. L). Pakistan. Journal of Food Science, 22(1), 12-22.

Rodriguez-Amaya, D. B., \& Kimura, M. (2004). HarvestPlus handbook for carotenoids analysis (Technical Monograph Series, Vol. 2). Washington: HarvestPlus.

Rosenkranz, R. R., \& Dzewaltowski, D. A. (2008). Model of the home food environment pertaining to childhood obesity. Nutrition Reviews, 66(3), 123-140. http://dx.doi.org/10.1111/j.1753-4887.2008.00017.x. PMid:18289177.

Sade, F. O., \& Aderonke, A. O. (2013). Physicochemical properties, vitamins, antioxidant activities and amino acid composition of ginger spiced maize snack 'kokoro' enriched with soy flour (a Nigeria based snack). Agricultural Sciences, 4(5), 73-77. http://dx.doi.org/10.4236/ as.2013.45B014.
Shukla, R., \& Cheryan, M. (2001). Zein: the industrial protein from corn. Industrial Crops and Products, 13(3), 171-192. http://dx.doi. org/10.1016/S0926-6690(00)00064-9.

Singh, S., Gamlath, S., \& Wakeling, L. (2007). Nutritional aspects of food extrusion: a review. International Journal of Food Science \& Technology, 42(8), 916-929. http://dx.doi.org/10.1111/j.13652621.2006.01309.x.

Sobota, A., \& Rzedzicki, Z. (2009). Effect of the extrusionprocess of corn semolina and pea hulls blends on chemical composition and selected physical properties of the extrudate. International Agrophysics, 23, 67-79.

Świątkiewicz, M., \& Bojanowski, J. (2004). Efficiency of ensilaged high-lysine maize grain in pig fattening. Journal of Animal and Feed Sciences, 13(2), 83-86.

Tako, E., Hoekenga, O. A., Kochian, L. V., \& Glahn, R. P. (2013). High bioavailability iron maize (Zea mays L.) developed through molecular breeding provides more absorbable iron in vitro (Caco-2 model) and in vivo (Gallus gallus). Nutrition Journal, 12(3), 3. http://dx.doi. org/10.1186/1475-2891-12-3. PMid:23286295.

Taverna, L. G., Leonel, M., \& Mischan, M. M. (2012). Changes in physical properties of extruded sour cassava starch and quinoa flour blend snacks. Ciência e Tecnologia de Alimentos, 32(4), 826-834.

Toops, D. (2012). Snacking could be the future of eating. Schaumburg: Food Processing. Retrieved from http://www.foodprocessing.com/ articles/2012/snacking-future-of-eating/

Venskutonis, P. R., \& Kraujalis, P. (2013). Nutritional components of amaranth seeds and vegetables: a review on composition, properties, and use. Comprehensive Reviews in Food Science and Food Safety, 12(4), 38-412. http://dx.doi.org/10.1111/1541-4337.12021.

Yan, J., Lipka, A. E., Schmelz, E. A., Buckler, E. S., \& Jander, G. (2015). Accumulation of 5-hydroxynorvaline in maize (Zea mays) leaves is induced by insect feeding and abiotic stress. Journal of Experimental Botany, 66(2), 593-602. PMid:25271262.

Ying, D. Y., \& Gantenbein-Demarchi, C. (2013). Probiotics and prebiotics. In G. W. Smithers \& M. A. Augustin (Eds.), Advances in dairy ingredients (pp. 269-290). Chichester: Wiley \& Sons. 